\title{
Investigation of Some Ion Selective and Water Repellent Properties of Carbazole Based Polymers
}

\author{
Aysel Aydin Kocaeren \\ Çanakkale Onsekiz Mart University, Faculty of Education, Department of Mathematics and Science Education, Çanakkale, Turkey \\ (ORCID ID: 0000-0003-4113-0517), aysel.kocaeren@,comu.edu.tr
}

(1st International Conference on Applied Engineering and Natural Sciences ICAENS 2021, November 1-3, 2021)

(DOI: 10.31590/ejosat.996942)

ATIF/REFERENCE: Aydın Kocaeren, A. (2021). Investigation of Some Ion Selective and Water Repellent Properties of Carbazole Based Polymers. Avrupa Bilim ve Teknoloji Dergisi, (28), 263-269.

\begin{abstract}
A polymer derived from poly-9-bis[4-(thiophen-3,4-yloxy)biphenyl)]-9H-carbazole containing a carbazole and thiophene group, abbreviated as $\mathrm{B} 2$, was synthesized via the oxidation method by using $\mathrm{FeCl}_{3}$ as an oxidant. Additionally, $\mathrm{P}(\mathrm{B} 2)$ was synthesized and coated onto an ITO-glass surface via electrochemical oxidative polymerization. UV spectra of these polymers and their metal complexes (like $\mathrm{Fe}^{2+}, \mathrm{Cd}^{2+}, \mathrm{Hg}^{2+}, \mathrm{Pb}^{2+}$ ) were recorded in DMSO solutions, and then their UV spectra depending on the concentration were recorded. According to the results, when the concentration was rising, the absorbance peak intensity increased gradually for B2. Also, for P(B2), the absorbance peak followed a fluctuating course. The photo images of its some metal complexes were recorded under UV light. Resultantly, B2 polymer was determined to be selective against $\mathrm{Fe}^{2+}$ ion and it can be said that B2 could be used as fluorescence Fe ${ }^{2+}$ ion probe. Finally, contact angle (CA) measurements of B2 and P(B2) were realized and, according to the recorded photo images it can be said that $\mathrm{B} 2$ had more hydrophobic property than $\mathrm{P}(\mathrm{B} 2)$.
\end{abstract}

Keywords: electrochemical polymerization; carbazole; thiophene; contact angle; metal complex.

\section{Karbazol Esaslı Polimerlerin Bazı İyon Seçici ve Su İtici Özelliklerinin İncelenmesi}

$\ddot{\mathbf{O z}}$

Yapısında bir karbazol ve tiyofen grubu içeren B2 olarak kısaltılan poli-9-bis[4-(tiyofen-3,4-iloksi)bifenil)]-9H-karbazol'den türetilen yeni bir polimer oksidan olarak $\mathrm{FeCl}_{3}$ ' ün kullanılmasıyla oksidasyon metoduyla sentezlendi. İlave olarak, $\mathrm{P}(\mathrm{B} 2)$ sentezlendi ve elektrokimyasal oksidatif polimerizasyonla ITO cam yüzeyi üzerine kaplandı. Bu polimerlerin ve onların $\left(\mathrm{Fe}^{+2}, \mathrm{Cd}^{+2}, \mathrm{Hg}^{+2}, \mathrm{~Pb}^{+2}\right.$ gibi) metal komplekslerinin UV spektrumları DMSO çözeltilerinde kaydedildi, ve daha sonra onların konsantrasyona dayalı UV spektrumları kaydedildi. Sonuçlara göre B2 için konsantrasyon arttı̆̆ında absorbans pik şiddeti kademeli olarak artmaktadır. Ayrıca, P(B2) için de absorbans piki dalgalı bir seyir izlemektedir. Bazı metal komplekslerinin fotoğraf görüntüleri UV ışığı altında kaydedildi. Sonuç olarak, B2 polimerinin $\mathrm{Fe}^{+2}$ iyonuna karşı seçici olduğu belirlendi ve B2' nin floresan $\mathrm{Fe}^{+2}$ iyon probu olarak kullanılabileceği söylenebilir. Son olarak B2 ve P(B2)' nin temas açısı (CA) ölçümleri yapılmış ve kaydedilen fotoğraf görüntülerine göre B2’nin P(B2)'den daha fazla hidrofobik özelliğe sahip olduğu söylenebilir.

Anahtar Kelimeler: Elektrokimyasal polimerizasyon; karbazol; tiyofen; kontak açısı; metal kompleks 


\section{Introduction}

Usually, electrochromic materials are obtained by electrochemical synthesis method and deposited on a conductive surface such as ITO (indium tin oxide) ${ }^{[1]}$. Electrochromic materials produced by electrochemical synthesis are generally based on monomeric electroactive compounds such as thiophene, carbazole, aniline, EDOT, pyrrole and their derivatives. Among these compounds, carbazole is preferred as the starting compound in scientific studies because of its suitable structure for electrochemical synthesis ${ }^{[2-4]}$.

Below, the advantages offered by the carbazole unit used in these studies are briefly mentioned:

1) It is a strong electron donating ( $p$-type) chromophore group.

2) Carbazole can be easily functionalized from the 3,6- or $N$ - positions. Therefore, different substituents can be easily attached to the carbazole ring ${ }^{[5]}$.

3) Carbazole-containing compounds show photochemical stability.

In a study conducted by Aydin and Kaya in the literature, oxidative polymerization is performed by using $\mathrm{FeCl}_{3}$ oxidant in chloroform solvent. According to this study, thermal measurements of polymers are performed by TGA-DTA analysis and residual amounts of polymers at $1000^{\circ} \mathrm{C}$ are determined. As a result, it is found that the thermal stability of the obtained polymers with $\mathrm{FeCl}_{3}$ is quite good [6,7]. It can be said that the oxidative polymerization process with $\mathrm{FeCl}_{3}$ can be preferred when it is aimed to obtain polymers having high thermal stability.

As is known, the use of optical sensors has become widespread in recent years. Optical sensors have various advantages in terms of low detection limit, high concentration range, good selectivity and sensitivity, being economical and easy to manufacture ${ }^{[8,9]}$. Therefore, these types of sensors serve detection technology in many application areas such as chemistry, biomedicine and environmental engineering ${ }^{[10]}$.

Recently the application areas of synthesized optical sensors form medicine and molecular biology. The chemical structure of the materials used in optical sensors is very important. Therefore, every compound cannot be used as an optical sensor. To manufacture optical sensors, functional groups such as ether bridges (C-O-C), carboxyl (-COOR) and amine $\left(-\mathrm{NH}_{2}\right)$ groups must be in the structure of the compounds. While producing the optical sensors, various ions $\left(\mathrm{Cd}^{2+}, \mathrm{Co}^{2+}, \mathrm{Fe}^{2+}, \mathrm{F}^{-}, \mathrm{Cl}^{-}, \mathrm{Br}^{-}, \mathrm{SO}_{4}{ }^{2-}\right.$, $\mathrm{NO}^{3-}, \mathrm{Zn}^{2+}, \mathrm{Ni}^{2+}, \mathrm{Pb}^{2+}, \mathrm{Cu}^{2+}, \mathrm{Hg}^{2+}, \mathrm{Ca}^{2+}, \mathrm{CO}_{3}{ }^{2-}, \mathrm{CH}_{3} \mathrm{COO}^{-}, \ldots$ etc.) are used. These ions can be diversified by the researcher depending on the purpose and target of the study ${ }^{[11,12]}$.

In addition to optical sensor applications, the study of electrochromic properties of metal sensitive compound has become popular in recent years. Such complex compounds are often used as electrochemical transistors. In particular, there is a need to develop poly-carbazole-derived compounds as ionselective microelectrochemical transistors ${ }^{[13]}$.

In this study, we chose carbazole as the starting compound due to the advantages of the carbazole as mentioned above and performed electropolymerization and oxidative polymerization processes on it. To investigate the ion selectivity properties of the compounds we used $\mathrm{Pd}^{2+}, \mathrm{Fe}^{3+}, \mathrm{Cu}^{2+}$ and $\mathrm{Co}^{2+}$ ions ${ }^{[14]}$ due to these kinds of ions that we have. In the article published by Danjou et al in 2012, the synthesis of a $N$-azacrown carbazole derived compound was carried out. It had been reported that this compound behaved selectively against $\mathrm{Fe}^{3+}$ ion in an aqueous environment ${ }^{[15]}$. Similarly, in this study it was determined that the synthesized polymer (B2) showed selectivity against $\mathrm{Fe}^{2+}$ ion. We wanted to investigate the water repellent characteristics of the obtained polymers due to their synthesis via thin film coating. Also, CA measurements of each polymer were carried out at volume of 5,81 and 4,34 $\mu \mathrm{L}$ for $\mathrm{P}(\mathrm{B} 2)$ and $\mathrm{B} 2$, respectively. According to the obtained results, the polymer $\mathrm{P}(\mathrm{B} 2)$ had no water repulsive property, but $\mathrm{B} 2$ is better in water repellency than $\mathrm{P}(\mathrm{B} 2)$ when see CA measurements.

\section{Material and Method}

\subsection{Materials}

Carbazole, 3,4-dibromo thiophene, ethanol, methanol, chloroform $\left(\mathrm{CHCl}_{3}\right)$, acetonitrile $(\mathrm{ACN})$, tetrahydrofuran (THF), $\mathrm{Cd}\left(\mathrm{CH}_{3} \mathrm{COO}\right)_{2} 2 \mathrm{H}_{2} \mathrm{O}, \quad \mathrm{Pb}\left(\mathrm{CH}_{3} \mathrm{COO}\right)_{2} 3 \mathrm{H}_{2} \mathrm{O}, \quad \mathrm{FeCl}_{3} 6 \mathrm{H}_{2} \mathrm{O}$ $\left(\mathrm{CH}_{3} \mathrm{COO}\right)_{2} \mathrm{Hg}$ and toluene were supplied from Merck Chemical Co. (Germany) and used as received. 4-iodo phenol was supplied from Aldrich Chemical Co. (USA). Boron trifluoride ethyl etherate $\left(\mathrm{BF}_{3} \mathrm{EtE}\right)$ was supplied from Fluka Chemical Co.

\subsection{Measurement Methods}

UV spectra were measured by Perkin Elmer Lambda 950 UV spectrophotometer, and used on Thermo Scientific Visioncollect Software programme for the purpose of viewing spectra. The CA measurements were carried out on fiber-modified Mg AZ31 alloys using a KSV Attension Theta Lite Optical Tensiometer with a sessile drop method. Polymer droplets of approximately 4.5-5 $\mu \mathrm{L}$ were deposited on glass surfaces with manually controlled Hamilton syringe. UV lamp was used to view interactions with metal complexes of synthesized polymers.

\subsection{Syntheses of $B 2$ and $P(B 2)$}

$\mathrm{B} 2$ and $\mathrm{P}(\mathrm{B} 2)$ were synthesized as in literature ${ }^{[1,16]}$ via oxidation method and electrochemical polymerization. The related articles were published by Kocaeren ${ }^{[17]}$ in scientific journal (See ref. 16 and 17). Additionally, the electrochemical polymerization conditions and the characterization data that illuminate the structures of $\mathrm{B} 2$ and $\mathrm{P}(\mathrm{B} 2)$ polymers were given in the experimental and results sections of these manuscripts. Possible coupling or binding positions of the obtained polymer with $\mathrm{FeCl}_{3}$ oxidant is shown as in literature (See ref. 16).

General synthesis scheme is given in Scheme 1, which shows the structures of $\mathrm{B} 1, \mathrm{~B} 2$ and $\mathrm{P}(\mathrm{B} 2)$ compounds. 


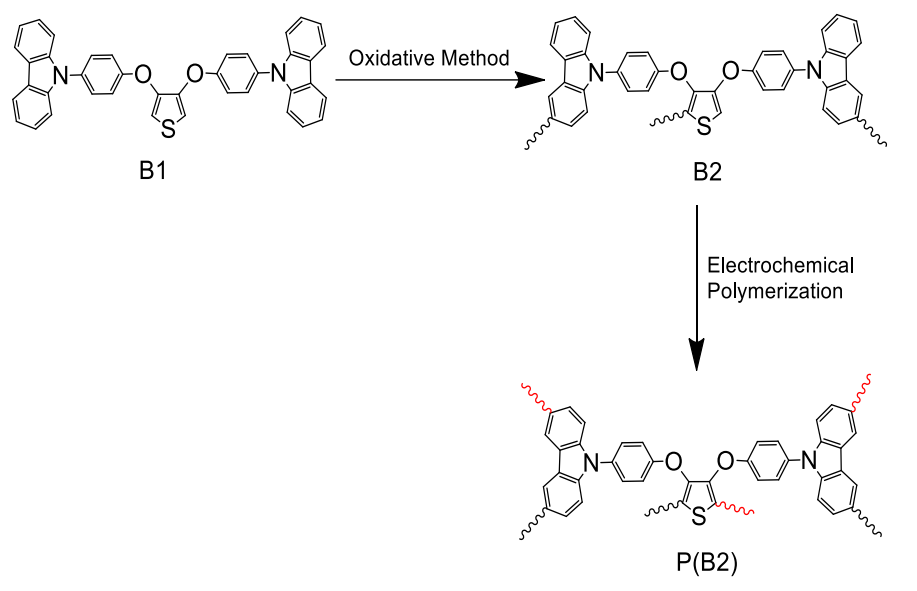

Scheme 1. Synthesis of the polymers performed by using $\mathrm{FeCl}_{3}$ oxidant via oxidative method and electrochemical polymerization

\subsection{Obtaining of $B 2$ and $P(B 2)$-metal complexes}

Solutions of $\mathrm{Cd}\left(\mathrm{CH}_{3} \mathrm{COO}\right)_{2} 2 \mathrm{H}_{2} \mathrm{O}, \quad \mathrm{Pb}\left(\mathrm{CH}_{3} \mathrm{COO}\right)_{2} 3 \mathrm{H}_{2} \mathrm{O}$, $\mathrm{FeCl}_{3} 6 \mathrm{H}_{2} \mathrm{O}$, $\left(\mathrm{CH}_{3} \mathrm{COO}\right)_{2} \mathrm{Hg}(1 \mathrm{mmol})$ in DMSO $(10 \mathrm{~mL})$ were separately added to a solution of $\mathrm{B} 2$ or $\mathrm{P}(\mathrm{B} 2)(2 \mathrm{mmol} / \mathrm{unit})$ in DMSO $(20 \mathrm{~mL})$, respectively. Then, polymer-metal complexes solutions were shaken well in UV tube. General viewing of ion complex formation is shown in Scheme 2, that is ion metal complex formation scheme of $\mathrm{P}(\mathrm{B} 2)$. B2 also can form ion metal complexes via the same mechanism.
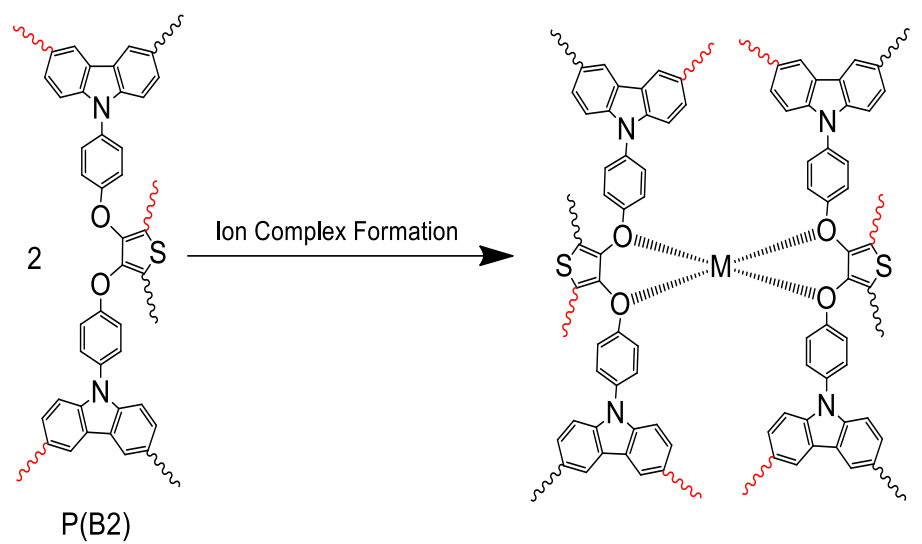

Scheme 2. General synthesis scheme of ion metal complex of $\mathrm{P}(\mathrm{B} 2)$

\section{Results and Discussion}

\subsection{Binding mechanism of metal to the synthesized polymers (B2 and $\mathrm{P}(\mathrm{B} 2)$ )}

The C-O-C (ether) groups in the structure of the compounds are expected to interact with the ions as mentioned above by coordinating covalent bonding. Since there are no functional groups (-C-O-C, $-\mathrm{COOR},-\mathrm{NH},-\mathrm{CH}=\mathrm{N}-\ldots$ etc.) attached to the thiophene ring in the structures of the synthesized compounds, there is no metal bonding through the thiophene ring ${ }^{[1,16,17]}$. Any metal-ion interaction through nitrogen atoms in the carbazole rings is not a subject due to the steric effect. In the studies in the literature, it has been determined from the UV spectra of the compounds that the groups containing $\mathrm{C}$ and $\mathrm{O}$ interact with ionic species such as $\mathrm{Pd}^{2+}, \mathrm{Fe}^{3+}, \mathrm{Cu}^{2+}$ and and $\mathrm{Co}^{2+}$ in a coordinated manner. Therefore, the synthesized polymers are expected to interact (forming complexes) with such ions via the C-O-C groups $[9,14]$. The only attachment or coordinating covalent bonding point may be possible through these groups. Scheme 3 shows binding mechanism of ion metal named as $\mathrm{M}^{2+}\left(\mathrm{Pd}^{2+}, \mathrm{Fe}^{3+}, \mathrm{Cu}^{2+}\right.$ and $\mathrm{Co}^{2+}$ ions) under UV light.

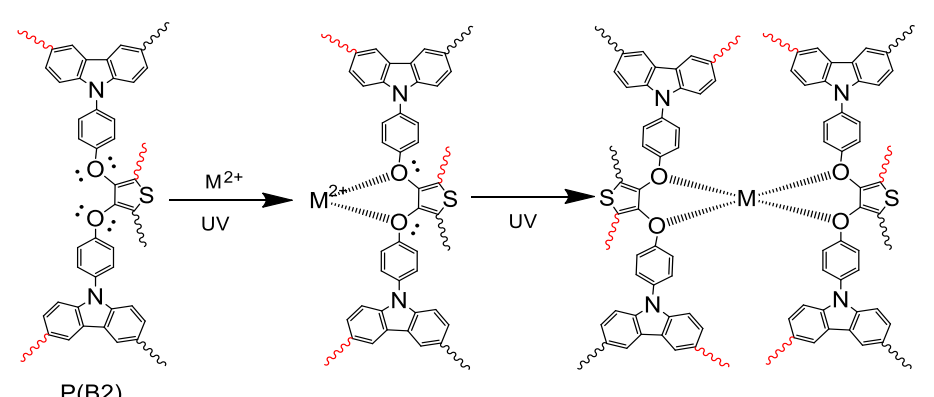

Scheme 3. Binding mechanism of ion metal $\left(\mathrm{M}^{2+}\right)$ under UV light.

\subsection{UV Spectra}

Ultraviolet-visible (UV-vis) spectra are measured by Perkin Elmer Lambda 950 UV spectrometer, and used on Thermo Scientific Visioncollect Software programme via viewing spectra. The absorption spectra are recorded by using DMSO solutions at room temperature $\left(25^{\circ} \mathrm{C}\right)$. The UV spectra simples of the polymers are prepared in DMSO at concentration of $5 \mathrm{mg} / 5 \mathrm{~mL}$ $(1.0 \mathrm{M})$, and similarly for that of their metal complexes are at concentration of $5 \mathrm{mg} / 5 \mathrm{~mL}$ in DMSO. Samples used in concentration measurements are prepared by diluting on these prepared solutions ${ }^{[18]}$. The UV-vis spectroscopic studies are carried out in DMSO solutions (v/v:4/1) of B2 and $\mathrm{P}(\mathrm{B} 2)$, and their metal complexes, respectively. The UV-vis spectra of the synthesized polymers are shown in Fig. 1. As seen in Fig. 1, B2 and $\mathrm{P}(\mathrm{B} 2)$ have different $\lambda_{\text {onset }}$ values such as $400 \mathrm{~nm}$ and $468 \mathrm{~nm}$. This result clearly indicates that the poly-conjugated derivative of $\mathrm{P}(\mathrm{B} 2)$ has higher $\lambda_{\text {onset }}$ value than its starting compound. Also, a red shift occurs at the absorption edges of the synthesized polymer in comparison to B2. This is because of the poly-conjugated structures of the polymers which increase HOMO and decrease LUMO energy levels thus results in lower band gaps. Resultantly, UV results show that the synthesized polymeric compound (P(B2)) has lower the optical band gaps as per its starting compound (B2), as expected. The adding more units together have been demonstrated for the formation of the polymeric conjugate $\pi$ system $^{[19]}$.

When investigate the UV spectrum of B2 polymer it can be seen that it has three maximum absorbance peaks. These are 224,$76 ; 248,24$ and $288,15 \mathrm{~nm}$, respectively. $\mathrm{P}(\mathrm{B} 2)$ has two absorbance peaks at 245, 31 and 276,49 $\mathrm{nm}$. Moreover, the other optical parameters of the compounds are given in Table 1. According to Table 1, $E_{\mathrm{g}}$ and $\lambda_{\text {onset }}$ values are 3,11 and 2,65; 400 and $468 \mathrm{~nm}$, respectively for B2 and $\mathrm{P}(\mathrm{B} 2)$, also the remarkable changes are observed in their spectra. For example, when $\mathrm{P}(\mathrm{B} 2)$ compared with $\mathrm{B} 2$, that has three different absorbance peaks as mentioned above. Additionally, $\mathrm{P}(\mathrm{B} 2)$ polymer has a red shift, which occurs at the absorption edge of $\mathrm{P}(\mathrm{B} 2)$ at approximately $320 \mathrm{~nm}$.

The optical band gaps $\left(E_{g}\right)$ could be obtained by using the following equation as in the literature ${ }^{[20]}$ : 
$E_{g}=1242 / \lambda_{\text {onset }}$

where $\lambda_{\text {onset }}$ is the onset wavelength which can be determined by intersection of two tangents on the absorption edges. $\lambda_{\text {onset }}$ also indicates the electronic transition start wavelength. The optical band gaps values for $\mathrm{B} 2$ and $\mathrm{P}(\mathrm{B} 2)$ are calculated as $3.11 \mathrm{eV}$, and $2.65 \mathrm{eV}$, respectively as mentioned above. This result shows that the $\mathrm{P}(\mathrm{B} 2)$ has lower optical band gap when compared with the B2 as expected. These results are in agreement with the literature data [21].

Table 1. Optical measurement parameters of the synthesized polymers

\begin{tabular}{|l|c|c|c|}
\hline Compounds & $\mathbf{E}_{\mathbf{g}}(\mathbf{e V})$ & $\lambda_{\max }(\mathbf{n m})$ & $\lambda_{\text {onset }}(\mathbf{n m})$ \\
\hline B2 & 3,11 & $\begin{array}{r}224,76 ; \\
248,24 ; \\
288,15\end{array}$ & 400 \\
\hline P(B2) & 2,65 & $\begin{array}{r}245,31 ; \\
276,49\end{array}$ & 468 \\
\hline
\end{tabular}

Figure 1 shows UV spectra of $\mathrm{B} 2$ and $\mathrm{P}(\mathrm{B} 2)$ depends on concentration, respectively. Also, to observe maximal absorbance values of the polymers are investigated and UV spectra of the synthesized polymers are obtained in different concentrations of their DMSO solutions. Firstly the concentration of the solutions is prepared as $0.5 \mathrm{M}$ and then they are diluted to the concentrations in range of 1.0, 1.5 and $2 \mathrm{M}$. If Fig. 1A is examined it can be seen that there is a significant increase in absorbance depends on concentration at certain wavelengths. As seen in Fig. $1 \mathrm{~B}$ significant increases in absorbance peak values in range of 0.5 and $1.5 \mathrm{M}$ are recorded but the absorbance peak is decreased at the concentration of $2 \mathrm{M}$. This decreasing can be clearly seen from the absorbance graph plotted against the concentration. Resultantly, for $\mathrm{P}(\mathrm{B} 2)$ when the concentration increases before the absorbance peak increases in range of 0.5 and $1.5 \mathrm{M}$ and then the absorbance peak has decreased at $2 \mathrm{M}$ concentration ${ }^{[22]}$.
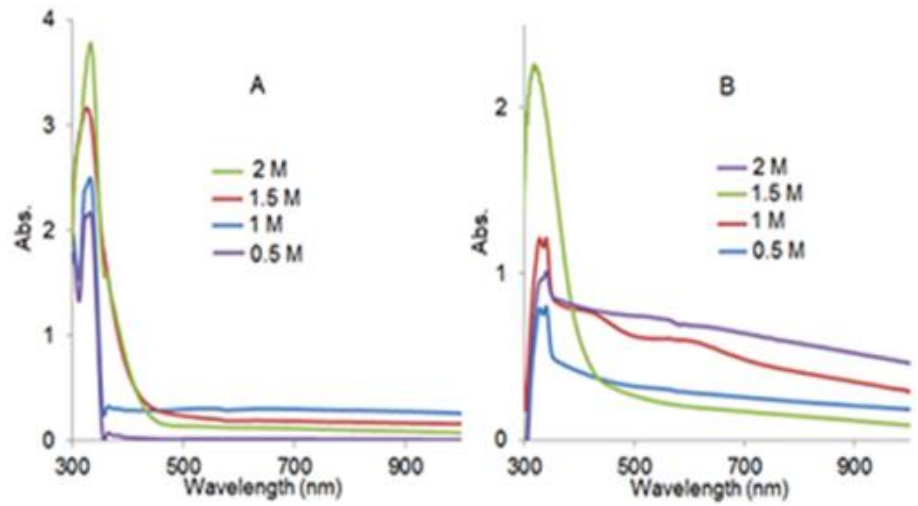

Fig. 1. UV spectra of A) B2 and B) $\mathrm{P}(\mathrm{B} 2)$ depends on concentration

The mentioned situation above can be explained more easily with Figure 2. According to this, the changing in absorbance peaks of B2 depending on concentration is linear but that of $\mathrm{P}(\mathrm{B} 2)$ is not linear, firstly it has a rising curve and a descending curve later. Therefore the correlation value $\left(\mathrm{R}^{2}=0,337259\right)$ is far from 1 , whereas as calculated 0,997993 the correlation value $\left(\mathrm{R}^{2}\right)$ of $\mathrm{B} 2$ e-ISSN: 2148-2683 is pretty close to $1^{[23]}$. It is drawn the absorbance changing graphs at maximum wavelengths in UV spectra of B2 and $\mathrm{P}(\mathrm{B} 2)$ to investigate the changing depending on absorbance. Thus, it can be seen that the absorbance changing at maximum wavelengths in UV spectrum of B2 is similar to Fig. 2A. But the correlation value is calculated as 0,7985998 and a linear curve has been obtained and that of $\mathrm{P}(\mathrm{B} 2)$ has a descending curve similar to Fig. $2 \mathrm{~B}$.
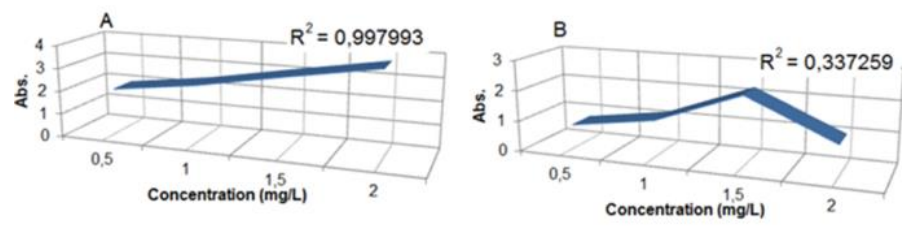

Fig. 2. Absorbance changing graphs of A) B2 and B) $\mathrm{P}(\mathrm{B} 2)$ depends on concentration

UV spectra of the metal complexes belonging to the polymeric compounds are shown in Fig. 3. As seen in Fig. 3B, that has a shift to the right in wavelengths of the metal complexes of $\mathrm{P}(\mathrm{B} 2)$. As mentioned above this is named as red shift and this is related to the poly-conjugated structure of the $\mathrm{P}(\mathrm{B} 2)$ polymer ${ }^{[24]}$. Also, its metal complexes have the same property and as a result of this, it is obtained in a widespread UV spectrum. However, UV spectra of B2 and its metal complexes are normally sharper in compared to $\mathrm{P}(\mathrm{B} 2)$ as seen in Fig. 3A.
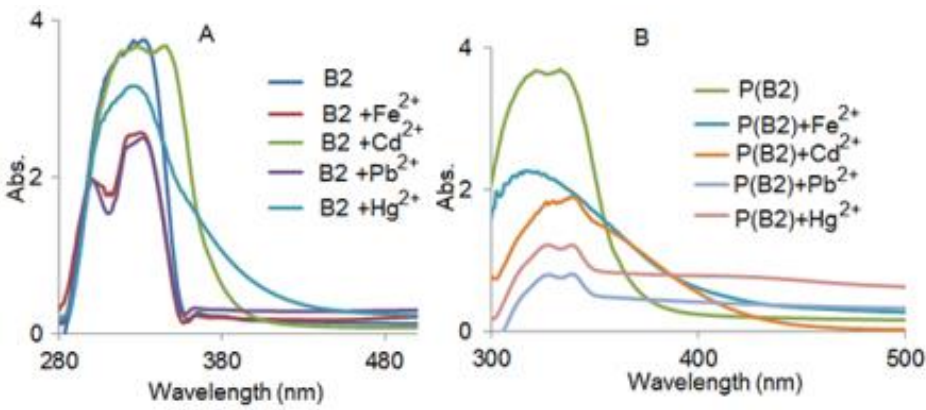

Fig. 3. UV spectra of A) B2 and B) P(B2), and their metal complexes

Additionally, the electronic parameters of the polymer-metal complexes are given Table 2. According to the Table 2, the optical band gaps of the compounds are different and as follows: $\mathbf{B 2}+$ $\mathbf{F e}^{2+}<\mathbf{B 2}+\mathbf{C d}^{2+}<\mathbf{B 2}+\mathbf{H g}^{2+}<\mathbf{B 2}+\mathbf{P b}^{2+}$ for $\mathrm{B} 2$, and $\mathbf{P}(\mathbf{B} 2)+$ $\mathbf{H g}^{2+}<\mathbf{P}(\mathrm{B} 2)+\mathbf{C d}^{2+}<\mathbf{P}(\mathbf{B} 2)+\mathbf{P b}^{2+}<\mathbf{P}(\mathbf{B} 2)+\mathbf{F e}^{2+}$ for $\mathrm{P}(\mathrm{B} 2)$, respectively. As investigated Table 2, except for $\mathrm{E}_{\mathrm{g}}$ value of metal complex with $\mathrm{Hg}^{2+}$ of $\mathrm{P}(\mathrm{B} 2), \mathrm{E}_{\mathrm{g}}$ values of the other metal complexes of $\mathrm{P}(\mathrm{B} 2)$ are higher than that of $\mathrm{B} 2$. Although $\mathrm{E}_{\mathrm{g}}$ values of metal complexes of $\mathrm{P}(\mathrm{B} 2)$ are higher than that of $\mathrm{B} 2, \mathrm{E}_{\mathrm{g}}$ value of $\mathrm{P}(\mathrm{B} 2)$ are obtained as $2.65 \mathrm{eV}$, as mentioned above. 
Table 2. Optical measurement parameters of the synthesized metal complexes of $\mathrm{B} 2$ and $\mathrm{P}(\mathrm{B} 2)$.

\begin{tabular}{|l|c|c|c|}
\hline Compounds & $\mathbf{E}_{\mathbf{g}} \mathbf{( e V )}$ & $\lambda_{\max }(\mathbf{n m})$ & $\lambda_{\text {onset }}(\mathbf{n m})$ \\
\hline $\mathbf{B 2}+\mathbf{F e}^{\mathbf{2 +}}$ & 2,61 & 315,59 & 476,03 \\
\hline $\mathbf{B 2}+\mathbf{C d}^{\mathbf{2 +}}$ & 2,73 & 336,01 & 454,53 \\
\hline $\mathbf{B 2}+\mathbf{P b}^{\mathbf{2 +}}$ & 3,44 & $\begin{array}{c}325,26 ; \\
336,1\end{array}$ & 360,74 \\
\hline $\mathbf{B 2}+\mathbf{H g}^{\mathbf{2 +}}$ & 3,35 & $\begin{array}{c}326,38 ; \\
337,21\end{array}$ & 370,41 \\
\hline $\mathbf{P}(\mathbf{B 2})+\mathbf{F e}^{\mathbf{2 +}}$ & 3,74 & 318,35 & 332,07 \\
\hline $\mathbf{P}(\mathbf{B} 2)+\mathbf{C d}^{2+}$ & 3,01 & 312,$60 ;$ & 412,30 \\
\hline $\mathbf{P}(\mathbf{B 2})+\mathbf{P b}^{\mathbf{2 +}}$ & 3,70 & 318,21 & 335,29 \\
\hline $\mathbf{P}(\mathbf{B 2})+\mathbf{H g}^{\mathbf{2 +}}$ & 2,89 & 312,75 & 429,85 \\
\hline
\end{tabular}

B2 and P(B2) are treated with the some metals $\left(\mathrm{Fe}^{2+}, \mathrm{Cd}^{2+}\right.$, $\left.\mathrm{Hg}^{2+}, \mathrm{Pb}^{2+}\right)$ in DMSO solvent. Figure 4 shows the photographs of interaction with $\mathrm{Fe}^{2+}, \mathrm{Cd}^{2+}, \mathrm{Pb}^{2+}$ and $\mathrm{Hg}^{2+}$ of $\mathrm{B} 2$ in DMSO solution, respectively under UV light. In the experiments, it was determined that the $\mathrm{B} 2$ behaves selectively against $\mathrm{Fe}^{2+}$ ion under UV light. But, the selectivity against any metal ions $\left(\mathrm{Fe}^{2+}, \mathrm{Cd}^{2+}\right.$, $\mathrm{Hg}^{2+}, \mathrm{Pb}^{2+}$ ) of $\mathrm{P}(\mathrm{B} 2)$ polymer could not be determined. Additionally, the photographs of $\mathrm{P}(\mathrm{B} 2)$-metal complex mixtures are taken under UV light, but no change observed. It can be said that $\mathrm{P}(\mathrm{B} 2)$ polymer interacts with metals due to the changes in their UV spectra. Since no change is observed in the photographs, it cannot be said that it is selective against the mentioned ions. It is estimated that the $\mathrm{Fe}^{2+}$ ions interacts through ether bridges $(\mathrm{C}$ O-C) in the structure of the compound ${ }^{[14]}$. Therefore, it can be said that $\mathrm{B} 2$ can be used as the fluorescence $\mathrm{Fe}^{2+}$ ion probe. Considering the widespread use of fluorescence probes in medicine and molecular biology in the next years, there will be a need for materials selective against $\mathrm{Fe}^{2+}$ and $\mathrm{Fe}^{3+}$ ions ${ }^{[15]}$. The synthesized polymer is important as it will allow the development of these materials ${ }^{[25]}$.

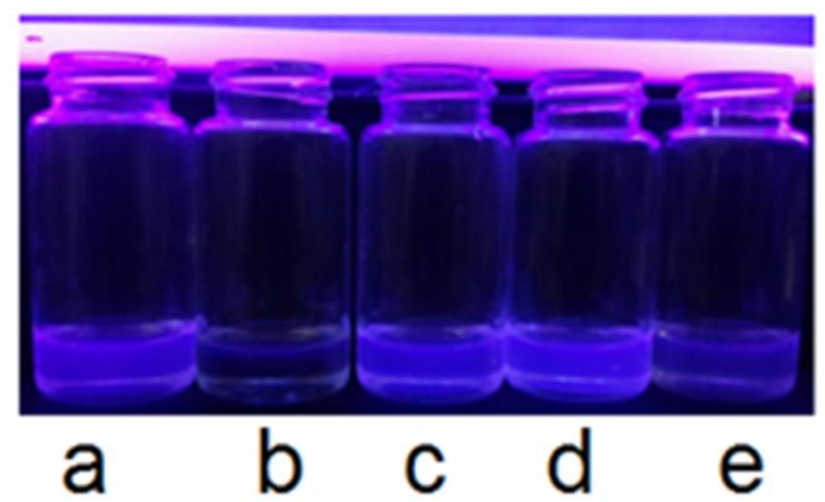

Fig. 4. Photographs of a) $\mathbf{B 2}$ and interaction with b) $\mathrm{Fe}^{2+}$, c) $\mathrm{Cd}^{2+}$, d) $\mathrm{Pb}^{2+}$ and e) $\mathrm{Hg}^{2+}$ of $\mathrm{B} 2$ in DMSO solution under UV light.

\subsection{Contact Angle (CA) Measurement}

CA measurement technique is used because of its simplicity. The contact angle (CA) is measured for determine polymers surface hydrophobicity. A simple set up is built which involved dropping a $100 \mu \mathrm{L}$ water droplet and measuring the advancing e-ISSN: 2148-2683 angle of contact ${ }^{[26]}$ between the droplet and the sample surface with graduated reticule and a 10X magnifying glass ${ }^{[27]}$. A simple of $\mathrm{P}(\mathrm{B} 2)$ in volume of $5,81 \mu \mathrm{L}$ is dropped onto the water covered glass surface. The time is approximately $4,8 \mathrm{~s}$ for both polymers. Other data obtained with CA left and right are given Table 3. As seen in Table 3, CA values of $\mathrm{P}(\mathrm{B} 2)$ are lower than B2, that means low hydrophobicitiy property.

In other words, considering the structures of the polymeric compounds, that contain ether groups and benzene rings ${ }^{[28]}$. According to litreture ${ }^{[29,30]}$, because of the hydrophilic ether groups and the hydrophobic benzene rings, the contact angle for the polymer B2 is decreasing to approximately $65^{\circ}$.

Table 3. Contact angle (CA) data of the compounds.

\begin{tabular}{|c|c|c|c|c|c|}
\hline Compounds & $\begin{array}{c}\text { Time } \\
{[\mathbf{s}]}\end{array}$ & $\begin{array}{c}\text { CA } \\
\left.\text { left }^{[}{ }^{\circ}\right]\end{array}$ & $\begin{array}{c}\text { CA } \\
\text { right }\left[{ }^{\circ}\right]\end{array}$ & $\begin{array}{c}\text { CA } \\
\text { mean }\left[{ }^{\circ}\right]\end{array}$ & $\begin{array}{c}\text { Volume } \\
{[\boldsymbol{\mu} \mathbf{L}]}\end{array}$ \\
\hline $\mathrm{P}(\mathrm{B} 2)$ & 4,85 & $29 \pm 2$ & $35 \pm 3$ & $32 \pm 3$ & 5,81 \\
\hline $\mathrm{B} 2$ & 4,74 & $65 \pm 1$ & $65 \pm 1$ & $65 \pm 1$ & 4,34 \\
\hline
\end{tabular}

Recent progress has indicated that surfaces with ideal roughness and microtextured structures have low interfacial free energies and remarkably high contact angles, as in the case of lotus leaves, the contact angle $(\mathrm{CA})$ of which is about $161.0 \pm 2.7^{\circ}$ ${ }^{[31-34]}$. Also, B2 has low CA value as $65^{\circ}$ thus it can be said that the synthesized polymers have generally hydrophilic property due to their low CAs. As seen in Fig. 5, it can be seen that B2 is a hydrophobic structured material than $\mathrm{P}(\mathrm{B} 2)$. This situation can be explained as follows:

The oxidative polymerization with $\mathrm{FeCl}_{3}$ may remove with influence of oxide groups in the structure of the specimen. These oxide groups have a given polarity which give them an attraction to water. Thus the hydrophobicity and the measured CA is decrease. However, these oxide groups have a higher surface free energy than the surrounding methyl groups ${ }^{[35]}$. Additionally, the realized electrochemical polymerization after the oxidative polymerization is further curtained these oxide groups since the resulting structure has longer polymer chain structures and more branched groups just like $\mathrm{P}(\mathrm{B} 2)$.

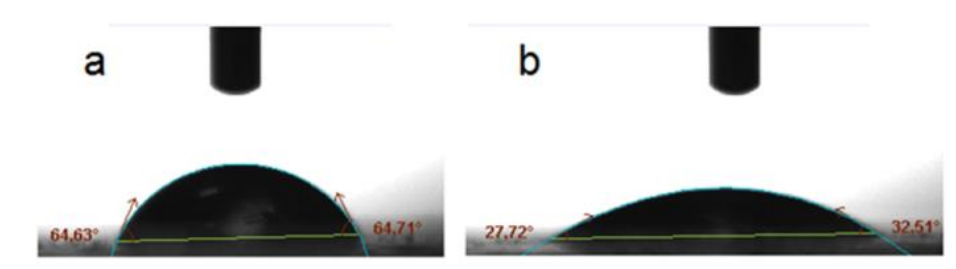

Fig. 5. Photo images of contact angle measurements of a) B2 and b) $\mathrm{P}(\mathrm{B} 2)$

\section{Conclusions and Recommendations}

Two polymers as named B2 and $\mathrm{P}(\mathrm{B} 2)$ were firstly synthesized by two different methods like oxidative polymerization with $\mathrm{FeCl}_{3}$ and electrochemical polymerization. Secondly, some metal complexes $\left(\mathrm{Fe}^{2+}, \mathrm{Cd}^{2+}, \mathrm{Hg}^{2+}, \mathrm{Pb}^{2+}\right)$ of these 
polymers were obtained in UV tub. We can understand that metal complexes are formed from the changes in their UV spectra. According to the analysis results, B2 polymer was determined to be selective against $\mathrm{Fe}^{2+}$ ion since it can be seen that the photographs of its some metal complexes were taken under UV light. It means that $\mathrm{B} 2$ could be used as fluorescence $\mathrm{Fe}^{2+}$ ion probe. Also, the UV spectra depend on their concentration at 0.5 , $1,1.5$ and $2 \mathrm{M}$ were recorded. Although for $\mathrm{P}(\mathrm{B} 2)$ as the concentration increased before the absorbance peak increased in range of 0.5 and $1.5 \mathrm{M}$ and then the absorbance peak decreased at $2 \mathrm{M}$ concentration while the concentration was rising, the absorbance peak intensity increased gradually for B2. Finally, CA measurements of $\mathrm{B} 2$ and $\mathrm{P}(\mathrm{B} 2)$ were realized and, according to obtained CA data it could be said that B2 had more hydrophobic property than $\mathrm{P}(\mathrm{B} 2)$.

\section{References}

1. Kocaeren, A.A., 2015. Electrochemical synthesis and electrochromic application of a novel polymer based on carbazole. Org. Electron. 24, 219-226.

2. Ramírez, A.M., Cattin, L., Bernède, J.C., Díaz, F.R., Gacitúa, M.A., del Valle, M.A., 2021. Nanostructured $\mathrm{TiO}_{2}$ and PEDOT electrodes with photovoltaic application. Nanomaterials-Basel. 11 (1), 107-114.

3. Kiss, L., Kovács, F., Kunsági-Máté, S., 2021. Electropolymerization of N,N'-diphenylguanidine in nonaqueous aprotic solvents and alcohols. Period. Polytech. Chem. Eng. 65 (1), 139-147.

4. Sheng, K., Li, L., Zhang, Q., Wang, Y.L., 2020. A highly sensitive sensor based on electropolymerization for electrochemical detection of esculetin. Microchem. J. 159, 105368-105373.

5. Grazulevicius, J.V., Strohriegl, P., Pielichowski, J., Pielichowski, K., 2003. Carbazole-containing polymers: synthesis, properties and applications. Prog. Polym. Sci. 28 (9), 1297-1353.

6. Aydın, A. Kaya, İ., 2013. Syntheses, characterizations and electrochromic applications of polymers derived from carbazole containing thiophene rings in side chain with electrochemical and $\mathrm{FeCl}_{3}$ methods. Org. Electron. 14 (3), 730-743.

7. Kocaeren, A.A., 2016. Synthesis and characterization of novel polymers based on carbazole with $\mathrm{NaOCl}$ and $\mathrm{FeCl}_{3}$ oxidants. Iran Polym. J. 25, 15-24.

8. Firooz, A.R., Ensafi, A.A., Hoseini, K.S., Kazemifard, N., 2014. Development of a highly sensitive and selective mercury optical sensor based on immobilization of bis(thiophenal)-4,4'methylenedianiline on a PVC membrane. Mat. Sci. Eng. C Mater Biol. Appl. 38, 73-78.

9. Zargoosh, K., Badadi, F.F., 2015. Highly selective and sensitive optical sensor for determination of $\mathrm{Pb}^{2+}$ and $\mathrm{Hg}^{2+}$ ions based on the covalent immobilization of dithizone on agarose membrane. Spectrochim. Acta A: Mol. Biomol. Spect. 137, 105110 .

10. Chiam, Y.S., Lim, K.S., Harun, S.W., Gan, S.N., Phang, S.W., 2014. Conducting polymer coated optical microfiber sensor for alcohol detection. Sensor Actuat. A 205, 58-62.
11. Zhang, L., Wen, Y., Yao, Y., Xu, J., Duan, X., Zhang, G., 2014. Synthesis and characterization of pedot derivative with carboxyl group and its chemo/bio sensing application as nanocomposite, 1mmobilized biological and enhanced optical materials. Electrochim. Acta 116, 343-354.

12. Echabaane, M., Rouis, A., Bonnamour, I., Ouada, H.B., 2013. Studies of aluminum (III) ion-selective optical sensor based on a chromogenic calix[4]arene derivative. Spectrochim. Acta Part A: Mol. Biomol. Spectrosc. 115, 269-274.

13. Saxena, V., Shirodkar, V., Prakash, R., 2000. Copper(II) ionselective microelectrochemical transistor. J. Solid S. Electrochem. 4, 234-236.

14. Cui, H., Liu, H., Chen, S., Wang, R., 2015. Synthesis of amphiphilic spiropyran-based random copolymer by atom transfer radical polymerization for $\mathrm{Co} 2+$ recognition. Dyes Pigments 115, 50-57.

15. Danjou, P.E., Lyskawa, J., Delattre, F., Becuwe, M., Woisel, P., Ruellan, S., Fourmentin, S., Cazier-Dennin, F., 2012. New fluorescent and electropolymerizable $\mathrm{N}$-azacrown carbazole as a selective probe for iron (III) in aqueous media. Sensor Actuat. B: Chem., 171-172, 1022-1028.

16. Kocaeren, A.A., 2016. A new polymer for OLEDs based on carbazole: white, turquoise blue and light orange colors. Int. J. Plast. Technol. 20 (1), 143-158.

17. Kocaeren, A.A., 2016. Synthesis and electrochromic performance of a novel polymer based on an oxidative polymer derived from carbazole and thiophene. J. Polym. Res. 23, 66-75.

18. Kaya, İ., Aydın, A., 2011. Synthesis and characterization of chelate polymers containing etheric diphenyl ring in the backbone: thermal, optical, electrochemical, and morphological properties. Polym. Adv. Technol. 22, 951-961.

19. Kaya, İ., Aydın, A., 2008. Synthesis, characterization, thermal stability, conductivity and band gaps of monomer and oligo-4-[(thien-2-ylmethylene) amino] phenol. e-Polymers 071, $1-15$.

20. Kaya, İ., Temizkan, K., Aydın, A., 2013. Synthesis and characterization of aromatic and aliphatic ether bridged polymers containing carbazole moieties. Mat. Sci. Eng. B 178 (13), $863-$ 874.

21. Tan, K.H., Samylingam, L., Aslfattahi, N., Saidur, R., Kadirgama, K., 2021. Optical and conductivity studies of polyvinyl alcohol-MXene (PVA-MXene) nanocomposite thin films for electronic applications. Opt. Laser. Tech. 136, 106772 106783.

22. Kaya, İ., Aydın, A., 2009. Synthesis, characterization, thermal degradation and electrical conductivity of oligo[2-(thien2-yl-methylene)aminophenol] and oligomer-metal complexes. Chinese J. Poly. Sci. 27 (4), 465-477.

23. Zhong, J.L., Mori, T., Kashiwagi, T., Yamashiro, M., Kusunose, S., Mimami, H., Tsujimoto, M., Tanaka, T., Kawashima, H., Nakagawa, S., Ito, J., Kijima, M., Iji, M., Watanabe, M.M., Kadowaki, K., 2021. Characteristic terahertz absorption spectra of paramylon and paramylon-ester compounds. Spectrochim. Acta Part A: Mol. Biomol. Spectrosc. 244, 118828-118834. 
24. Midoune, A., Messaoudi, A., 2021. DFT/TDDFT studies of the structural, electronic and NBO properties of some complexes with the tetrathiafulvalene-1,3-benzothiazole ligand. Inorganica Chim. Acta 516, 120151-120158.

25. Tong, Y.L., Zeng, Z.H., Yu, K., Bao, J.Q., Yin, J.J., 2020. A fiber optic sensor for 2,4-dichlorophenol analysis based on optical composite oxygen-sensitive film. J. Wuhan Univ. Techn.- Mater. Sci. Ed. 35, 743-749.

26. Horzum Polat, N., Kap, O., Farzaneh, A., 2018. Anticorrosion coating for magnesium alloys: electrospun superhydrophobic polystyrene/ $\mathrm{SiO}_{2}$ composite fibers. Turk. J. Chem. 42, 672-683.

27. Gorur, R.S., Chang, J.W., Amburgey, O.G., 1990. Surface hydrophobicity of polymers used for outdoor insulation. T. Power Del. 5 (4), 1923-1933.

28. Rathnayake, R.M.N.M., Mantilaka, M.M.M.G.P.G., Hara, M., Huang, H.H., Wijayasinghe, H.W.M.A.C., Yoshimura, M., Pitawala, H.M.T.G.A., 2017. Graphite intercalated polyaniline composite with superior anticorrosive and hydrophobic properties, as protective coating material on steel surfaces. Appl. Surf. Sci., 410, 445-453.

29. Ding, H., Zhu, C., Zhou, Z., Wan, M., Wei, Y., 2006. Hydrophobicity of Polyaniline Microspheres Deposited on a Glass Substrate. Macromol. Rapid Commun. 27, 1029-1034.

30. Zhou, C., Gong, X., Qu, Y., Han, J., 2016. Hydrophobic and high adhesive polyaniline layer of rectangular microtubes fabricated by a modified interfacial polymerization. Appl. Surf. Sci., 379, 124-131.

31. Makar, G.L., Kruger, J., 1993. Corrosion of magnesium. Int. Mater. Rev. 38, 138-153.

32. Aghion, E., Bronfin, B., Eliezer, D., 2001. The Role of the magnesium industry in protecting the environment. J. Mater. Process. Technol. 117 (3), 381-385.

33. Kleiner, M., Geiger, M., Klaus, A., 2003. Manufacturing of lightweight components by metal forming. CIRP Ann. Manuf. Technol. 52 (2), 521-542.

34. Huo, H., Li, Y., Wang, F., 2004. Corrosion of AZ91D magnesium alloy with a chemical conversion coating and electroless nickel layer [J]. Corros. Sci. 46, 1467-1477.

35. Berger, T., Sundhararajan, S., Nagaosa, T., 1997. Influence of temperature on the hydrophobicity of polymers. Confer. Electr. Insul. Dielectr. Minneapolis, 394. 